\section{Research Article}

(c) 2020 Ekpoh et.al.. This is an open access article licensed under the Creative Commons Attribution-NonCommercial 4.o International License (https://creativecommons.org/licenses/by-nc/4.o/)

\title{
Security Challenges in Universities: Implications for Safe School Environment
}

\author{
Uduak Imo Ekpoh
}

Aniefiok Oswald Edet

Nse Nkereuwem Ukpong

Department of Educational Management,

University of Calabar, Calabar, Nigeria

DOI: https://doi.org/10.36941/jesr-2020-0113

\begin{abstract}
This study researched on security challenges in universities and the implications for safe school environment. Three hundred and twenty five (325) samples, constituting 50\% of a population of 650 security personnel in two universities in the study area participated in the study. The study was based on three research questions and one hypothesis. Data for the study was gathered through a 42-item questionnaire. The questionnaire was validated and tested for reliability using Cronbach Alpha with a reliability index of 0.87 . Data collected were analyzed using means, standard deviation and independent $t$-test. Results indicated that cult-related activities, kidnapping, drug abuse/offences, illegal possession of fire arms by students, students' restiveness/demonstrations, students' union election crisis, room break-in, stealing and pilfering and sexual assaults were the most prevalent security challenges. Findings also showed that inadequate security personnel, insufficient patrol vehicles, poor lighting of university environments, non-availability of modern security facilities, poor funding of security departments, porous campus environments, lack of security-awareness education, non-availability of electronic gadgets among others were the factors militating against effective security checks in universities. Implications for safe school environment were discussed, and one of the recommendations was that the security unit should be well funded and equipped with modern technology by the university management for a better performance.
\end{abstract}

Keywords: Security challenges, universities, safe school environment

\section{Introduction}

The university is a learning organization and as such attracts students, staff and other stakeholders who have one thing or the other to carry out in the university environment. Hence, the issue of security comes to play. The university exists as a complex organization with heterogeneous identity comprising people from different backgrounds with distinct views and divergent goals that make it susceptible to varied security threats. Oladikpo, Awoyinfa and Adefarakan (2018) define security as the degree of protection against danger, damage, loss, and criminal activity. In the same vein, Oni (2016), considers security in the university as the protection of tangible and intangible assets of the institution from all forms of danger. The tangible assets as indicated by the author include; the physical structures, books in the libraries, electronic gadgets, all stakeholders, the players involving the regular and occasional visitors to universities. On the other hand, intangible assets include, intellectual property, research 
data, classified information, integrity, peace of mind, the image of the university and so on. The main aim of security according to Tari (2004) is to ensure safety and security of staff, students and visitors, protecting the property and assets of the university, investigating and detecting crime, reducing incidence of reported crimes and the apprehension and prosecution of offenders.

Globally, there is a rising wave of insecurity and the universities are not spared from this problem. The rising wave of insecurity in universities has been a source of great concern recently. In the 6os, $70 \mathrm{~s}$ and up to 8os, educational environments were relatively peaceful for teaching-learning process to go on without hindrance. However, the situation has changed since in the 9os. Recent happenings have shown that university environments are not so safe for the students and for the school personnel any more due to some threatening security challenges. In line with this Mensah, Baafi, Arthur, Somuah, and Mprah (2019) observed that university campuses are no longer safe havens. Similarly, Enang (2019) noted that university communities in recent times have been infested with all manner of criminalities which, quite sadly, paint an opaque and rather disheartening picture. Abdullahi and Orukpe (2016) and Enang (2019) observed that theft, cultism, kidnapping, rape, room break-in, office break-in, cell-phone snatching, stealing, violent demonstration by students, vandalism and other forms of assaults are major security challenges on campuses. Caleb (2013), also noted that cultism has proved to be a major concern for even existing security agencies on campuses. In the same vein, Oladipo, Awoyinfa and Adefarakan (2018) observed that the existence of cultist groups on campus have made life unsafe and scary to both staff and students. It is asserted that the cultist possess, in many cases, more deadly and functioning weapons than campus security agencies and often use supernatural and mystical powers in their activities. Besides, many cult members are users of hard drugs, and can act in unthinkable ways when they are under its influence. Cultists are implicated in robbery, killing of innocent students, as well as academic and non-academic staff, arson, rape, extortion, kidnapping, blackmail and all kinds of inhumane practices. Oladipo et al. (2018) further enumerated the activities of cultists to include, harassing any non-member who snatches a member's girlfriend or sugar daddy (as in the case of a female cultist), harassing female students who refused their advances, as well as, harassing any lecturer who insists on merit for passing examination. They also engage in factional struggles for supremacy that often results in bloody clashes among cult groups, during which period lives are sometimes lost. This has made Ibrahim (2013) to posit that, higher institutions of learning which ought to be ideal places for training of the minds have become war zones where cult groups unleash their terror in the community.

According to Badiora (2017), "the spectra of crimes on the campuses of tertiary institutions in Nigeria have grown to an alarming rate and level, that it has remained a permanent issue in national discourse" (p. 18o). Unfortunately, this has adversely affected the academic and social life of both staff and students on campus. These waves of crises have brought additional responsibilities for the school authorities to provide adequate security. In the past, security officers were expected to be reactive checking on potential risks and responding when something happened. However, as observed by Rosenbery (2014), "a security officer is an integral, proactive part for creating a safe environment, preparing for all hazards, as well as, actively promoting a safer place to study, work and visit. Perhaps the most dramatic paradigm shift in security operations, is the change from security officers being behind-the-scene enforcers and responders, to serving as collaborative promoters of the college's culture (P.1)". In corroboration, Beard (2010) noted that an open and proactive approach to identifying and mitigating risk is crucial in building a safety culture in which members' perceptions are positive. In the same vein, Lawrence (2007) posited that school security has changed, requiring well-developed security and safety plans, as well as, proper risk management, together with well-articulated strategies and procedures to protect schools from crimes and threats.

As a way of finding solution to increasing security challenges in universities, the Federal Government of Nigeria in a one day workshop organized for Deans and Deputy Deans of Students Affairs of Federal Institutions in Nigeria in 2016, on the theme "Towards the effective security/safety on campuses", tasked the participants to take the issue of security seriously by fashioning out solutions to the seeming intractable security challenges facing the nation/university. The workshop was part of the series of security/safety seminars to sensitize management officers in tertiary institutions about 
security management with a view to reducing insecurity to the barest minimum in the campuses (Idoko, 2017).

Every university has a responsibility to protect itself, the students, staff and other customers who visit the university for one form of transaction or the other, from all forms of danger. The National School Board Association (2013) identified the responsibility of all schools to include, giving adequate safety and security against disasters, accidents, injuries, as well as, prepare proactive plans that investigate perceived threats and disasters. It is in this regard that every university has a wellestablished security unit, whereby security personnel are employed to handle the school security and ensure that lives and properties are protected and secured. The duties of these security officers include protection of lives/property, surveillance, gathering and dissemination of security intelligence, among others. University campuses as observed by Schneider Electric (as cited in Abdullahi and Orukpe, 2016) are dynamic environments with constant activity, which require an effective security unit that would address the protection and safe guarding of students, staff, visitors, faculty, property and facilities on campus. Good security services not only help to prevent crimes, but also contribute to a positive image of the institution by creating a safe and welcoming environment for students, staff, and visitors.

Maintaining security in any organization is a complex issue and the quality of security services depend on a number of factors, one of which is the caliber of staff. A casual observation indicates that some personnel employed in the security units hardly had any formal training on security matters. As a result, it not only exposes their client to serious security risk but also the security personnel themselves as well, when there are security threats. As a matter of policy, the chief security officer in a university must have basic training in any military or paramilitary organization, however, many other security personnel have no professional training whatsoever on crime prevention, e-security, security intelligence, aborting crime or reading crime motive of prospective intruders. Another major impeding factor in the maintenance of security on campus is that most security personnel on campus do not wield gun and, as a result, university campuses are left vulnerable to the menace of criminal-minded individuals who carry guns and conduct their operations without any hindrance. Besides, most security units lack necessary facilities and modern technologies needed to fight crimes on campus. Security personnel cannot discharge their duties effectively without adequate facilities. It is also observed that most institutions of learning are porous and do not have perimeter fencing, which is critical in preventing access by intruders, securing assets, and protecting personnel or buildings.

Safe-guarding the academic environment for educational activities is very important. It is for this reason that Okebukola (as cited in Youdeowei and Iruoma, 2015) posits that "no safe school, no future for the world". The author gave three reasons to justify this assertion as follows; (i) The dream of harnessing the power of education for achieving goals in health, food, employment, enrolment, energy, security will come to naught.(ii) Without safe schools, education for all will remain a pipe dream (iii) Quality education yearned by all countries of the world will be hindered. Xaba (2014) describes safe school environment as one that is not dangerous and possess no threats to physical, emotional, psychosocial and psychological well-being of the occupants. In other words, it is an environment that is secured and free from threat and danger.

The need to re-position the security personnel in the universities to effectively discharge their duties in relation to the emerging security issues and challenges cannot be overemphasized. The rising students and staff population, together with new crime types bring about more responsibilities on the security personnel, which calls for new strategies to tackle them. This is needful because as cautioned by Gomme and Micucci (1997), the perception of campus as a dangerous place may erode the quality of academic and social life for students, faculty, as well as, undermining a school's ability to attract and retain both clientele and personnel. It is against this background that this study is conducted to examine security challenges in universities and the implications for a safe school environment. The objectives of the current study are in four-fold: The first being to find out the security challenges in universities in Cross River State, Nigeria. Secondly, to examine the factors militating against effective security checks in universities. Thirdly, to examine the strategies for managing security challenges in Universities, and finally, to discuss the implications for a safe school environment. 
In recent past, Nigeria has recorded incidents of security threats in educational institutions as follows:

1. In 2011, students of University of Calabar went on rampage over increase in school charges, destroying buildings, facilities, cars and entering staff residential areas to destroy houses and staff properties worth millions of Naira. The security personnel were over powered by the rioting students. This incident resulted in the loss of academic months (Ekpoh, 2018).

2. In 2012, about 40 students of Federal Polytechnics Mbubi were massacred by Boko Harram terrorist group.

3. In 2013, students of university of Abuja demonstrated over non-provision of adequate laboratory facilities for medical and engineering students, which led to failed accreditation.

4. In 2013, students of University of Uyo rioted against school authorities due to increase in intracampus transport fare, as well as, insufficient lecture halls. This led to the destruction of school properties on campus and also the loss of a students' life.

5. On August $16^{\text {th }}$ 2013, a female student of Abia State University was held hostage for over one hour and gang-raped by persons suspected to be cultists.

6. On $18^{\text {th }}$ December 2013, suspected cultists attacked and killed Dr. Segun Onabanjo, a Senior Lecturer in The Department of Sociology of Olabisi Onabanjo University (OOU), Ogun State.

7. On $3^{\text {rd }}$ April 2015, Mrs. Awala George, a lecturer in University of Port Harcourt was kidnapped but later freed by police operatives eight days later (Oni, 2016).

8. On April $14^{\text {th }} 2014$, about 276 girls were abducted from Government Secondary School, Chibok. The girls were in the process of writing their school certificate examination. This particular incidence attracted global condemnation. Some of the girls have been released while others are still in captivity till date.

9. In July 2015, an 18 year old admission seeker in University of Lagos was raped by a lecturer.

10. In August 29, 2015, a $4^{\text {th }}$ year law students of the University of Calabar was sexually assaulted by her lecturer.

11. In the University of Calabar Staff Quarters, lecturers were attacked and three persons were kidnapped on May $23^{\text {rd }} 2016$. The incidence of 23 rd May led to one week withdrawal of service by academic staff.

12. In July 2016, a female under-graduate of Babcock University, Ogun State, kidnapped her friend in order to make money from the parents (Oladipo et al 2016).

13. In 2017, a Professor in the Department of Zoology, University of Calabar was kidnapped by gunmen while he was jogging in campus at about $6.40 \mathrm{am}$. The kidnapped lecturer was dragged for over 100 meters on the road by his abductors amidst intense gun shooting, before whisking him away to a waiting boat at the Big Qua River that borders the university.

14. On $16^{\text {th }}$ January 2017 , two suicide bombers attacked University of Maiduguri, killing three people including a professor.

15. On $19^{\text {th }}$ February, 2018, 111 secondary school girls from Government Girls Science and Technical College, Dapchi, Yobe were abducted.

16. In May 2019, a final year male student in Cross River State University of Technology was butchered in the classroom by persons suspected to be rival cultist group.

17. On February 17, 2020, an Associate Professor in the Institute of Public Administration, University of Calabar was kidnapped in his house. The sum of N50 million ransom was demanded by his abductors.

18. In April 2020, three students of university of Port Harcourt were kidnapped, killed and subsequently buried in a shallow grave.

19. On $27^{\text {th }}$ May, 2020 some suspected assassins entered University of Calabar staff quarters and killed a policeman on duty and escaped with his gun. The suspects escaped without being apprehended.

All these incidents are just the tip of the iceberg of security challenges in institutions of learning. 
It is an indication that school environments are under siege of security threatening incidents. In most of these attacks, the school security personnel are never well prepared to prevent or intervene in the security threats. There are many other incidents and some were never reported, hence the true extent of the situation may never be known.

\section{Literature Review}

A number of researches have been conducted to examine issues of security threats in Universities and other institutions of learning. For instance, Dagogo (2005) carried out a study on the role of security agents in curbing crimes in higher institutions in North East Nigeria using four universities and three polytechnics. The sample was 900 respondents who were purposively selected for the study. The data were analyzed using population t-test and the result revealed that training and re-training of security personnel significantly affect their level of service delivery. Odidison (2004) found out in his study on factors responsible for insecurity in Nigerian tertiary institutions using 500 security personnel that lack of training of security personnel was one of the factors that significantly accounted for the insecurity in Nigerian institutions.

Amoatemaa, Kyeremah and Arthur (2017) conducted a study on students' perception of campus safety in Ghana. Using 224 respondents, findings showed that $87.5 \%$ of the respondents indicated that students felt safer during the day time than night time. Also, it showed that isolated places and poorly lit areas of campus posed security threats. The findings further indicated that bushy areas, lack of close circuit television (CCTV), absence of police patrols and emergency phones to call the security officers, were the major factors contributing to students feeling of insecurity on campus. In another study by Chekwa, Thomas and Jones (2013) using 20 college students, it was found by $85 \%$ of the respondents that burglary was the number one crime committed on campus. Also, the security features that the respondents considered most important as a deterrent to criminal activities in the order of importance were; security officer, cameras, emergency call boxes and lighting. Audible emergency alert system was not considered as a factor in preventing crimes in the study.

Another study by Ozmen, Dur and Akgul (2010) on school security problems and ways of tackling them found that there were various problems threatening school security, which included lack of family interest, inadequate physical condition, and disruptive school environment, among others. The study recommended the development of emergency action plan to handle threatening and destructive conditions, as well, as building emergency communication line to link up necessary units and organizations to receive timely support and help in threatening situations. Oladipo et al (2018) examined institutional factors that served as threats to personnel security in University of Lagos and found that there existed a strong positive relationship between school location, school culture, school facilities and personnel security, while a weak, positive correlation existed between school climate and personnel security. The study concluded that hostile school environment, over-stretched and inadequate learning facilities, indiscipline, outdated security framework, poor staff and students' safety and security awareness, inadequate capacity building for security personnel, poor funding of institutions and so on, were the major determinants of security lapses on campus.

Badiora (2017) assessed patterns of crime on campuses: A spatial analysis of crimes and concerns for safety at a Nigerian University. Findings showed the five most frequently occurring crimes on campus to be; stealing and pilfering, room break-in, sexual harassment, cultism, and drug offences. In another study by Paul and Igwebuike (2018) on security challenges and management strategies in secondary schools, it was found that kidnapping, armed robbery, militancy, drug abuse, vandalism, theft and cultism were some of the security challenges experienced in the schools studied in Aba Education Zone, Abia State.

From the review of literature, it is observed that there is no empirically tested research on security challenges in universities in Cross River State, hence the relevance of the present study. The current study focuses on the perspective of security personnel on the security challenges in universities. 


\section{Statement of the Problem}

In recent times, university campuses in Cross River State have witnessed an upsurge in criminality and security threats. There are reported cases of stealing, vandalism, raping, killing, kidnapping and numerous other crimes in university campuses. There are cases of cultist clashes in campuses whereby human lives are lost. On a number of occasions, thieves and armed robbers have attacked students' hostels and staff quarters, stealing properties. In view of these happenings, one is inclined to wonder whether security personnel who are specifically employed to protect lives and properties are no longer effective in the discharges of their duties.

Some factors could be responsible for the apparent lack of capacity by security personnel to cope with contemporary challenges. For instance, it is evident that some security personnel under study do not have adequate and regular training to cope with the advanced level of criminality that is on the increase in university campuses and are therefore unable to operate modern security gadgets with efficiency. Also, most of the security personnel do not have formal training on security management. Besides, the few that are professionals do not have opportunity for capacity building programmes to update their skills and knowledge in crime management. It is generally observed that the security personnel lack basic facilities to use and combat crimes and, as such, are easily overwhelmed by the criminals. It is from this perspective that a research on security challenges in universities: Implications for safe school environment is timely.

\section{Research Questions}

The study will answer the following research questions:

1. What are the security challenges in universities?

2. What are the factors militating against effective security checks in universities?

3. What are the strategies for effective management of security challenges in Universities?

\section{The Study Hypothesis}

There is no significant difference between security challenges in University of Calabar and Cross River University of Technology.

\section{Methodology}

Descriptive survey design was used in this study. As the name implies, the survey accurately and systematically describes a situation or phenomenon. Accordingly, the design was considered appropriate to assess and describe the current state of security challenges in universities in Cross River State. Quantitative approach was utilized in conducting the study. Data used in the study were collected from two universities in Cross River State; University of Calabar (UNICAL) and Cross River University of Technology (CRUTECH). UNICAL is a federal government owned university while CRUTECH is a state owned university. Population of the study comprised 650 security personnel. Accidental sampling strategy was adopted to draw a sample of 325 respondents for the study. This figure represented $50 \%$ of the population. Of this number, 175 respondents were from UNICAL while, 150 were from CRUTECH. This strategy was utilized because security personnel run shift-work schedule and it was difficult to get them to administer the questionnaire. A questionnaire tagged "Security Challenges Questionnaire" was developed, validated and tested for reliability using Cronbach Alpha. The reliability index was 0.87 which was adjudged good for the utilization of the instrument. The questionnaire had 42 items and comprised two parts (Section A and Section B) based on the objective of the study. Section A was on demographic data (4 items), while section B was sub-divided into three sections as follows; security challenges ( 14 items), militating factors against effective security ( 13 items) and strategies for effective management of security (11 items). The items in section B were rated on a 
4-point scale of strongly agree-4 points, agree-3 points, disagree-2 points and strongly disagree-1 point.

The researchers sought the permission of the Chief Security Officers of each institution before administering the questionnaire to security personnel. Data collection period lasted for two months. The retrieved copies of the questionnaire were coded and the data analyzed using means, standard deviation and independent t-test.

\section{Result}

\subsection{Research question 1: What are the security challenges in universities?}

To answer this research question, means and standard deviation were used. Result is as presented in Table 1.

Table 1: Mean and Standard deviation of the responses to security challenges in universities in Cross River State, Nigeria

\begin{tabular}{clcccc}
\hline S/N & Security challenges & N & X & S.D & Decision \\
\hline 1 & Cult-related activities & 325 & 3.20 & 0.76 & Accepted \\
2 & Kidnapping & 325 & 2.66 & 0.76 & Accepted \\
3 & Rape & 325 & 2.32 & 0.69 & Rejected \\
4 & Drug abuse/offences & 325 & 2.84 & 0.77 & Accepted \\
5 & Illegal possession of fire arms by students & 325 & 2.88 & 0.71 & Accepted \\
6 & Students-community clashes & 325 & 1.92 & 0.69 & Rejected \\
7 & Incursion of herdsmen into campus & 325 & 1.82 & 0.84 & Rejected \\
8 & Students' restiveness/riots/demonstrations & 325 & 2.66 & 0.69 & Accepted \\
9 & Students' union election crisis & 325 & 2.65 & 0.74 & Accepted \\
10 & Encroachment into school land & 325 & 1.92 & 0.87 & Rejected \\
11 & Room break-in & 325 & 3.05 & 0.61 & Accepted \\
12 & Robbery & 325 & 2.49 & 0.75 & Rejected \\
13 & Stealing and pilfering & 325 & 3.10 & 0.56 & Accepted \\
14 & Sexual harassment & 325 & 2.74 & 0.66 & Accepted \\
& Grand Mean & & 2.59 & & Accepted \\
\hline
\end{tabular}

Cut off mean $=2.50$

Table 1 shows the Means and Standard deviations of the responses to security challenges in universities in Cross River State, Nigeria. The items were measured on a 4-point scale, making the highest response score on each item to be 4 and the least response score to be 1 . However, the cut-off mean, 2.50 was obtained as the average score of the highest and least score on each of the items. It could be observed that the following nine items, out of 14 listed, obtained mean that is equal to or above the cut-off mean: Cult-related activities (3.20); Kidnapping (2.66); Drug abuse/offences (2.84); Illegal possession of fire arms by students (2.88); Students' restiveness/riots/demonstrations (2.66); Students' union election crisis (2.65); Room break-in (3.05); Stealing and pilfering (3.10); Sexual harassment (2.74). This result indicates that the listed nine items were perceived by the respondents to be security challenges in the universities studied. The Grand Mean was seen to be, 2.59, which is also above the cut-off mean. This indicated acceptance that the items individually contributed as a security challenge at different weights, which is based on the mean of each item. The higher the mean, the more the item is perceived as a challenge. For example, cult-related activities have the highest mean, and could be considered the most security challenge in the studied institutions, followed by stealing and pilfering. Rape (2.32); Students-community clashes (1.92); Incursion of herdsmen into campus (1.82); Encroachment into school land (1.92); and Robbery (2.49) were seen to have their means less than the cut-off mean of 2.50. The five items were, however, not accepted as security challenges in the institutions studied. 
7.2 Research question 2: What are the factors militating against effective security checks in universities?

To answer this research question, means and standard deviation were used. Results is presented in Table 2.

Table 2: Mean and Standard deviation of the responses to factors militating against effective security checks in universities in Cross River State, Nigeria

\begin{tabular}{clcccc}
\hline S/N & Militating factors against effective security & N & X & SD & Decision \\
\hline 1 & Non availability of modern security facilities & 325 & 3.17 & 0.77 & Accepted \\
2 & Poor funding of security department & 325 & 3.10 & 0.77 & Accepted \\
3 & Lack of security awareness education & 325 & 2.85 & 0.74 & Accepted \\
4 & Uncontrolled human traffic into campus & 325 & 2.72 & 0.66 & Accepted \\
5 & Non professionalization of the security department & 325 & 2.19 & 0.65 & Rejected \\
6 & Porous campus environment & 325 & 3.08 & 0.79 & Accepted \\
7 & Lack of policy framework on security & 325 & 2.25 & 0.79 & Rejected \\
8 & Non availability of electronic monitoring gadgets & 325 & 2.83 & 0.73 & Accepted \\
9 & Inadequate/lack of training programmes for security personnel & 325 & 2.76 & 0.73 & Accepted \\
10 & Poor lighting of university environment at night & 325 & 3.30 & 0.75 & Accepted \\
11 & Insufficient patrol vehicles & 325 & 3.41 & 0.66 & Accepted \\
12 & Lack of motivation for security personnel & 325 & 2.58 & 0.73 & Accepted \\
13 & Inadequate security personnel & 325 & 3.45 & 0.63 & Accepted \\
& Grand Mean & & 2.90 & & Accepted \\
Cut off mean $=2.50$ & & & &
\end{tabular}

Table 2 shows the Means and Standard deviations of the responses to factors militating against effective security in universities in Cross River State, Nigeria. The following 11 items, out of 13 listed, obtained mean that is equal to or above the cut-off mean: Non availability of modern security facilities (3.17); Poor funding of security department( 3.10); Lack of security-awareness education ( 2.85); Uncontrolled human traffic into campus (2.72); Porous campus environment (3.08); Non availability of electronic monitoring gadgets ( 2.83); Inadequate/lack of training programmes for security personnel ( 2.76); Poor lighting of university environment at night (3.30); Insufficient patrol vehicles (3.41); Lack of motivation for security personnel (2.58); Inadequate security personnel (3.45). This indicated that the listed eleven items were perceived by the respondents to be factors militating against effective security checks in universities in the study area. The Grand Mean was seen to be 2.90, which is also above the cut-off mean. This indicates acceptance that the individual items contributed as factors militating against effective security at different weights, which is based on the mean of each item. The higher the mean, the more the item is perceived as a contributing factor. For example, inadequate security personnel has the highest mean, and could be considered most contributing factor against effective security in the studied institutions, followed by insufficient patrol vehicles. Non professionalization of the security department (2.19) and Lack of policy framework on security (2.25) were seen to have their means less than the cut-off mean of 2.50. The two items were however, not accepted as factors militating against effective security in the institutions studied.

7.3 Research question 3: What are the strategies for effective management of security challenges in Universities?

To answer this research question, means and standard deviation were used. Result is presented in Table 3. 
Table 3: Mean and Standard deviation of the responses to strategies for managing security challenges

\begin{tabular}{|c|c|c|c|c|c|}
\hline $\mathrm{S} / \mathrm{N}$ & Strategies for effective security management & $\mathrm{N}$ & $\mathrm{X}$ & SD & Decision \\
\hline 1 & Deployment of advance technology & 325 & 3.15 & 0.76 & Accepted \\
\hline 2 & Provision of sufficient surveillance vehicle & 325 & 3.02 & 0.70 & Accepted \\
\hline 3 & Use of CCTV cameras & 325 & 3.46 & 0.69 & Accepted \\
\hline 4 & Training programmes for personnel & 325 & 2.76 & 0.71 & Accepted \\
\hline 5 & Adequate funding of security departmental & 325 & 2.93 & 0.76 & Accepted \\
\hline 6 & Proper lighting of university environment & 325 & 3.05 & 0.67 & Accepted \\
\hline 7 & Provision of emergency alert system & 325 & 2.75 & 0.72 & Accepted \\
\hline 8 & Effective communication system & 325 & 3.47 & 0.65 & Accepted \\
\hline 9 & Provision of security equipment & 325 & 3.26 & 0.66 & Accepted \\
\hline 10 & Partnership with security agencies to reinforce school security (prevent crimes) & 325 & 3.47 & 0.68 & Accepted \\
\hline \multirow[t]{2}{*}{11} & Improvement in the welfare package of security personnel in universities & 325 & 3.03 & 0.71 & Accepted \\
\hline & Grand Mean & & 3.12 & & Accepted \\
\hline Cut & off mean $=2.50$ & & & & \\
\hline
\end{tabular}

Table 3 indicates the Mean and Standard deviations of the responses to strategies for managing security challenges in universities in Cross River State, Nigeria. All the 11 items obtained mean that was equal to or above the cut-off mean of 2.50. This indicates that: deployment of advance technology, provision of sufficient surveillance vehicle, use of CCTV cameras, training programmes for personnel, adequate funding of security department, proper lighting of university environment, provision of emergency alert system, effective communication system, provision of security equipment, partnership with security agencies to reinforce school security (prevent crimes), improvement in the welfare of security personnel in universities, are all acceptable strategies for managing security challenges in the study institutions. The Grand Mean was seen to be 3.12, which is also above the cut-off mean. This indicates acceptance that the individual items contributed as strategies for managing security challenges at different weights, which is based on the mean of each item. The higher the mean, the more the item is perceived as a higher contributing factor. For example, effective communication system and partnership with security agencies have the highest mean of 3.47, and could be considered most perceived strategies for managing security challenges in the studied institutions, followed by use of CCTV cameras, provision of security equipment, and others.

7.4 The Study Hypothesis: There is no significant difference between security challenges in University of Calabar and Cross River University of Technology.

To test the hypothesis, independent t-test was used. Result is presented in Table 4.

Table 4: Independent t-test analysis of the difference in security challenges between University of Calabar and Cross River University of Technology.

\begin{tabular}{lcccccc}
\hline Security challenges & Institution affiliation & $\mathrm{N}$ & $\mathrm{X}$ & $\mathrm{S} . \mathrm{D}$ & $\mathrm{t}$ & P-value \\
\hline Cult-related activities & UNICAL & 175 & 3.14 & 0.79 & -1.55 & .122 \\
Kidnapping & CRUTECH & 150 & 3.27 & 0.72 & & \\
& UNICAL & 175 & 2.73 & 0.78 & 1.56 & .119 \\
Rape & CRUTECH & 150 & 2.59 & 0.74 & & \\
& UNICAL & 175 & 2.08 & 0.58 & $-7.39^{*}$ & .000 \\
Drug abuse/offences & CRUTECH & 150 & 2.61 & 0.70 & & \\
& UNICAL & 175 & 2.72 & 0.69 & $-2.97^{*}$ & .003 \\
Illegal possession of fire arms by students & CRUTECH & 150 & 2.97 & 0.84 & & \\
& UNICAL & 175 & 2.83 & 0.65 & -1.42 & .157 \\
Students-community clashes & CRUTECH & 150 & 2.94 & 0.77 & & \\
& UNICAL & 175 & 1.88 & 0.74 & -1.13 & .259 \\
& CRUTECH & 150 & 1.97 & 0.63 & & \\
& & & & & &
\end{tabular}




\begin{tabular}{|c|c|c|c|c|c|c|}
\hline Security challenges & Institution affiliation & $\mathrm{N}$ & $\mathrm{X}$ & S.D & $\mathrm{t}$ & P-value \\
\hline \multirow[t]{2}{*}{ Incursion of herdsmen into campus } & UNICAL & 175 & 1.26 & 0.50 & $-18.80^{*}$ & .000 \\
\hline & CRUTECH & 150 & 2.48 & 0.66 & & \\
\hline \multirow[t]{2}{*}{ Students' restiveness/demonstrations } & UNICAL & 175 & 2.59 & 0.70 & -1.73 & .084 \\
\hline & CRUTECH & 150 & 2.73 & 0.66 & & \\
\hline \multirow[t]{2}{*}{ Students' union election crisis } & UNICAL & 175 & 2.40 & 0.66 & $-7.02^{*}$ & .000 \\
\hline & CRUTECH & 150 & 2.94 & 0.73 & & \\
\hline \multirow[t]{2}{*}{ Encroachment into school land } & UNICAL & 175 & 1.58 & 0.73 & $-8.50^{*}$ & .000 \\
\hline & CRUTECH & 150 & 2.32 & 0.85 & & \\
\hline \multirow[t]{2}{*}{ Room break-in } & UNICAL & 175 & 2.93 & 0.58 & $-3 \cdot 74^{*}$ & .000 \\
\hline & CRUTECH & 150 & 3.18 & 0.61 & & \\
\hline \multirow[t]{2}{*}{ Robbery } & UNICAL & 175 & 2.33 & 0.67 & $-4 \cdot 38^{*}$ & .000 \\
\hline & CRUTECH & 150 & 2.68 & 0.79 & & \\
\hline \multirow[t]{2}{*}{ Stealing and pilfering } & UNICAL & 175 & 3.01 & 0.59 & $-3.38^{*}$ & .001 \\
\hline & CRUTECH & 150 & 3.21 & 0.50 & & \\
\hline \multirow[t]{2}{*}{ Sexual harassment } & UNICAL & 175 & 2.72 & 0.63 & -0.46 & .648 \\
\hline & CRUTECH & 150 & 2.75 & 0.68 & & \\
\hline \multirow[t]{2}{*}{ Overall for security challenges } & UNICAL & 175 & 34.19 & 2.71 & $-13 \cdot 97^{*}$ & .000 \\
\hline & CRUTECH & 150 & 38.65 & 3.04 & & \\
\hline
\end{tabular}

$\mathrm{P}<.05 ; \mathrm{df}=323 ;$ critical $\mathrm{t}=1.968$

Table 4 shows the independent t-test analysis of the difference in security challenges between UNICAL which is a federal owned university and CRUTECH, which is a state-owned university. Out of 14 security challenges compared, eight showed significant difference, since their p-values were less than .05 and their $t$-values greater than critical $t$-value of 1.968 and degree of freedom 323. They are as follows: rape, $\mathrm{t}=-7.39(\mathrm{p}=.000<.05)$; drug abuse, $\mathrm{t}=-2.97(\mathrm{p}=.003<.05)$; incursion of herdsmen into campus, $\mathrm{t}=-$ $18.80(p=.000<.05)$; students union election crisis, $t=-7.02(p=.000<.05)$; encroachment into school land, $\mathrm{t}=-8.50(\mathrm{p}=.000<.05)$; room break-in, $\mathrm{t}=-3.74(\mathrm{p}=.000<.05)$; robbery, $\mathrm{t}=-4.38(\mathrm{p}=$ $.000<.05)$;stealing and pilfering, $\mathrm{t}=-3.38(\mathrm{p}=.001<.05)$. This leads to the acceptance that there is significant difference between UNICAL and CRUTECH in security challenges regarding rape, drug abuse, incursion of herdsmen into campus, students' union election crisis, encroachment into school land, room break-in, robbery and stealing. The negative t-values shows that the second comparison group, which is CRUTECH has higher mean value, indicating higher level of occurrence. This implies that CRUTECH which is state-owned university has significantly those security challenges more than UNICAL which is federal owned university. The overall for security challenges show a significant $\mathrm{t}$ value of $-13.97(\mathrm{p}=.000<.05)$. This means that overall, CRUTECH faces more security challenges than UNICAL. The other six items, cult-related activities, kidnapping, illegal possession of fire arms by students, student community clashes, students' restiveness and sexual harassment did not show significant difference. Their $\mathrm{p}$-values were greater than .05 and their $\mathrm{t}$-values were less than critical $\mathrm{t}$ value of 1.968. This implies that there is no significant difference between UNICAL and CRUTECH in security challenges regarding the six items.

\section{Discussion of Results}

The result of this study shows that there are many security challenges faced by universities in Cross River State. The challenges as indicated by security personnel include: cult-related activities, kidnapping, drug abuse/offences, illegal possession of fire arms by students, students' restiveness/demonstrations, students' union election crisis, room break-in, stealing and pilfering and sexual assaults. There are some predisposing factors for this result. A casual visit to the institutions studied reveals that there is paucity of control and access. Individuals could walk or drive through the gates into the institutions with no checks. In the process, criminals, armed robbers or kidnappers could just go through and unleash mayhem on unsuspected members of the university community and escape without being apprehended. This result is in consonance with the observation of Enang (2019), 
that university communities in recent times have been infested with criminalities due to unrestricted access. The findings of the study also corroborate the assertion by Ibrahim (2013) that no educational institution in the modern day Nigeria is free from security challenges. Also, the study outcome supports the observation of Oni (2016) that a huge gap still exists in the areas of crime deterrent and detection. This is seen in the extent of exposure to security challenges in universities.

The result of data analysis for the second research question shows a wide array of factors militating against the maintenance of effective security in the two universities studied. The factors as found in this study in the order of importance are inadequate security personnel, insufficient patrol vehicles, poor lighting of university environments, non-availability of modern security facilities, poor funding of security departments, porous campus environments, lack of security awareness education, non-availability of electronic gadgets, inadequate training programmes for security personnel, uncontrolled human traffic into campus and lack of motivation for security personnel. The findings of this study is as should be expected because public universities in Nigeria are under-funded, whereas security business is capital intensive. Consequently, there is a major lack of infrastructure in many institutions that could have been used in fighting crimes. In most instances, criminals are always better armed than security personnel. Another plausible explanation for this result is that the two universities studied have porous borders into the institutions. Hence, criminal-minded individuals could enter the institutions and perfect their assaults without being caught. University of Calabar for instance shares boundary with Qua River, which gives criminals quick escape route through water ways without being apprehended. Similarly, CRUTECH has porous perimeter fence, whereby neighboring communities use the institutions to have access to their homes. Besides, the needed security manpower in terms of quantity and quality to fight crimes is inadequate. Also, the surveillance personnel on campus in most cases are not armed and do not have the required intelligence of getting ahead of the criminals. In other words, reactive approach is always taken rather than proactive, to prevent crimes.

With regard to research question three, among the identified strategies for managing security challenges in universities are; effective communication system, partnership with security agencies to reinforce school security, use of CCTV cameras, provision of security equipment, adequate funding of security department, deployment of advance technology, proper lighting of university environment, provision of sufficient surveillance vehicles, improved welfare packages, training of security personnel, among others. All these strategies are required to enhance effective security in universities without which, campus security will be seriously compromised and the university environment will be increasingly vulnerable to security threats.

The findings of the only hypothesis tested in this study shows that there is significant differences in security challenges faced by UNICAL and CRUTECH. In other words, CRUTECH which is a stateowned university faces more security challenges than UNICAL which is a federal-owned university. A possible explanation for this finding is that UNICAL being a federal university is better funded and as such have better facilities with more security personnel than CRUTECH. Lack of appropriate resources to fight crime can prove disastrous. Besides, CRUTECH is located in Calabar South Local Government Area that is volatile and noted for criminal activities. Also, CRUTECH has porosity of security network with many access points into the institution that are not well checked, as well as, providing route to neighboring environs.

\section{Implications for Safe School Environments}

The findings of this study show that the two universities used in the present study face many security challenges. This does not augur well for academic programmes to thrive, because, security is a necessary precondition for the goals of education to be achieved. It is the responsibility of every institution to guarantee a conducive, secure and threat-free environment for effective teaching and research to take place. The security department in the university, has the onerous task of protecting the students, staff, and all customers who visits the University for any kind of transaction, from all forms of danger. As pointed out by Enang (2019), an effective security architecture in a university must 
be ahead of others in developing counter-measures to all possible threats in the environments, whether real or perceived. In the same vein, Ibrahim as cited in Faithful and Mbiraeye (2016), contend that an educational institution with an insecure environment is susceptible to distractions and possible disintegration. Thus, it behooves the university management to strengthen their security unit and intelligence net-works to contain the numerous security challenges and threats in institutions of learning.

\section{Conclusion and Recommendations}

The security challenges in universities constitute a serious threat to safe academic environment and hinders academic activities. The elimination of these threats from the universities should be paramount for meaningful academic work to thrive. The university management must be proactive in creating and sustaining a peaceful, threat-free environment through the following:

1. The security unit should be well funded and equipped with modern technology by the university management.

2. Provision of sufficient surveillance vehicles. This will be very useful in timely fighting and containment of criminal activities on campus.

3. Access into the university environment should be checked. Currently, people who have no business in the school are found everywhere. Access should be restricted.

4. All identified cultists should be rusticated from the institution by the university management. Linkages should be established with other institutions of learning so that such students are denied re-admission. Also, students arrested on involvement in heinous crimes should be suspended and handed over to law enforcement agencies for prosecution.

5. Management of the university should consider as utmost importance the installation of CCTV at strategic locations to monitor movements of persons for possible detection of criminal activities within the institution.

6. Security units in the university should be well staffed with qualified personnel. Recruitment of security personnel should be tailored towards getting those with experience and passion. Security department should not be an all comers affair.

7. Regular training and retraining programmes should be organized for all security personnel to sharpen their skills and acquaint them with modern trends in intelligent gathering, crime detention and security operation.

8. Security is every body's business, hence there is need for security awareness by both staff and students in order to stay safe.

\section{References}

Abdullahi, A., \& Orukpe, P. E. (2016). Developing of an integrated campus security alerting system. Nigerian Journal of Technology, 35(4), 895-903.

Amoatemaa, A. S., Kyeremeh, D. D., \& Arthur, Y. D. (2017). Students' perception of campus safety: A case of Kumasi Campus of Education, Winneba, Ghana. Asian Research Journal of Arts $\mathcal{E}$ Social Sciences, 3(1), 1-9.

Badiora, A. I. (2017). Pattern of crime on campuses: A spatial analysis of crime and concern for safety at a Nigerian university. Journal of Criminology, Special Edition 30(3), 180-200.

Beard, J. (2010). Students' perception of safety on the campus, Tennessee State University. ETD collection. Paper AA11476479. Retrieved from ProQuest Digital Dissertation

Caleb, A. (2013, January, 10). How safe are Nigerian campuses? Vanguard News. Retrieved from https//www.vanguardngr.com/2013/o1/how-safe-are-nigerian-campuses.

Chekwa, C., Thomas, E., \& Jones, V. J. (2013). What are college students' perceptions about campus safety? Contemporary Issues in Educational Research, 6(3), 325-232.

Dagogo, C. C. (2005). Environment development and military activity: Towards alternative security doctrines. Oslo: Universiteforlaget. 
Ekpoh, U. I. (2018). Assessing students' satisfaction with service delivery: Implications for educational management, Global Journal of Arts, Humanities and Social Science, 6(6), 48-60).

Enang, I. I. (2019). Strengthening campus internal security against criminalities and unacceptable conducts. Paper presented at security workshop for Association of Heads of Security of Tertiary institutions at University of Calabar from $26^{\text {th }}-28^{\text {th }}$ June, 2019 .

Faithful, D., \& Mbiraeye, F. (2016, June, 4). The rising insecurity in Nigerian campuses and the way forward-education. Naira Forum. Retrieved from https://www.nairaland.com/3146760/rising-insecurity-nigerian-campuses.

Gomme, I. \&Micucci, A. (1997). Loose connections: Crime and policing on university campus. The Canadian Journal of Higher Education, XXVII (1), 41-68.

Ibrahim, M. B. (2013). Security challenges in educational institutions: The way forward, a paper presented at annual lecture of Zaria Education Development Association (ZEDA). On Friday $27^{\text {th }}$ December, 2013.

Idoko, C. (2017, June, 8). FG tasks tertiary institutions on security on campuses $>>$ Education $>>$ Tribune Online. Retrieved from https://tribuneonline.com/96382.

Lawrence, R. (2007). School crime and juvenile justice, $2^{\text {nd }}$ Edition. New York: Oxford University Press.

Mensah, F. O., Baafi, J. A., Arthur, Y. D., Somuah, C. O., \& Mprah, R. (2019). Campus security and safety models: Statistical empirical analysis from a Ghana tertiary institution. Journal of Education and Practice, 10(12), 52-

National School Boards Association (2013). School safety, security, and emergency preparedness.www.nsba.org.

Odidison, J. O. (2004). Factors responsible for insecurity in Nigeria. Journal of Social Science, 20 (1) 31-42.

Oladipo, S. A., Awoyinfa, J. O., \& Adefarakan, O. S. (2018). Institutional critical factors in university personnel security. International Journal of Innovative Business Strategies (IJIBS). 4 (2), 219-227.

Oni, J. A. (2016). Combating security challenges in the university system. Paper presented at National Conference of Nigerian Universities professional Administrators CANUPA, 2016

Ozmen, F., Dur, C., \& Akgul, T. (2010). School security problems and ways of tackling them. Procedia Social and Behavioral Sciences, 2, 5377-5383.

Paul, A. J. N. \& Igwebuike, F. K (2018). Security challenges and management strategies in public secondary schools in Aba Education Zone of Abia State. Journal of Economics and Environmental Education, 3(1), 95-104.

Rosenberg, G. (2014, May, 27). 5 major issues campus security officers will face today. Security. Retrieved from https://www.security magazine.com/article/85537-major-issues-cc.

Tari, B. N. (2004). A perspective into students' politics in Nigerian Universities: A review. Journal of Curriculum and Instruction, 1(1), 79-87.

Xaba, M. I. (2014). A holistic approach to safety and security at schools in South Africa. Mediterranean Journal of Social Sciences, 5(20), 1580-1589.

Youdeowei, T., \& Iruoma, K. (2015, October, 22). Safety in schools: Matters arising. Vanguard Retrieved from https://www.vanguardngr.com/2015/10/safety-in-schools-matters-arising. 